\title{
ANALISIS TINGKAT KEPUASAN PELANGGAN TERHADAP PELAYANAN PT PELNI (PERSERO)
}

\author{
Arif Fatkur Rohman, Bambang Syairudin, Endah Angreni \\ Magister Manajemen Teknologi, Fakultas Bisnis dan Manajemen Teknologi \\ Institut Teknologi Sepuluh Nopember (ITS) \\ e-mail: arif@arayainternusa.com, bambangsy@ie.its.ac.id, endah@mmt-its.ac.id
}

\begin{abstract}
Development and competition business of transporting had been restrictive. Each operators race competition do innovation, efficiency, and continuous improvement. The customers of PT Pelni from year to year continues to decrease. Although actually PT Pelni also improve themselves, repair service and innovation, but still be unable to improve the number of passengers. This study attempts to know the level customer satisfaction PT Pelni to make known well and innovation that has done is in line with hope customers. The measurement of the customer satisfaction PT Pelni done with the approach servqual method. Aspects which are under consideration includes 5 dimensions main namely tangibles, reliability, responsiveness, assurance, and empathy which divided in 29 indicators variable. This research using respondents as the sample. Data analysis used the analysis method servqual and cartesious diagrams. The research results show that there are inconquirity between hope customers by the fact experienced. The largest is in dimension tangible, with the gap an average of -1,3. While gap smallest there are in dimension responsiveness -0,42. Analysis by diagram cartecious show you some attribute in the main priority improvement: furnishings that high quality (2), facilities shopping centers on a vessel (4), the availability of a bed with the corresponding numbers of a ticket (6), size cabin large (7), and the condition a clean room (8). All those attributes including in dimension of tangible.
\end{abstract}

Keywords: service quality, transportation, PT Pelni

\section{PENDAHULUAN}

\section{Latar Belakang}

PT Pelayaran Nasional Indonesia (Persero) yang didirikan sejak tanggal 28 Februari 1952 berdasarkan Surat Keputusan Menteri Perhubungan Nomor M.2/1/2, adalah perusahaan pelayaran nasional yang menyediakan jasa angkutan transportasi laut, meliputi jasa angkutan penumpang dan muatan barang antar-pulau. Status PT Pelni mengalami dua kali perubahan, pada tahun 1961 pemerintah menetapkan perubahan status dari perusahaan perseroan menjadi perusahaan negara (PN) dan dicantumkan dalam Lembaran Negara RI No. LN 1961. Kemudian pada tahun 1975 status perusahaan diubah dari perusahaan negara (PN) menjadi Perseroan Ter- batas (PT) Pelni sesuai dengan Akta Pendirian No. 31 tanggal 30 Oktober 1975. Perubahan tersebut dicantumkan dalam Berita Negara RI No. 562-1976 dan Tambahan Berita Negara RI No. 60 tanggal 27 Juni 1976.

Saat ini perusahaan mengoperasikan 28 unit kapal penumpang tiga unit kapal barang. PT Pelni (Persero) dalam melaksanakan tanggung jawabnya tidak hanya terbatas melayani rute komersial, tetapi juga melayani pelayaran dengan rute pulau-pulau kecil terluar.

Saat ini perusahaan mengoperasikan 28 unit kapal penumpang dan tiga unit kapal barang. PT Pelni (Persero) dalam melaksanakan tanggung jawabnya tidak hanya terbatas melayani rute komersial, tetapi juga melayani pelayaran dengan rute pulau-pulau kecil terluar. 


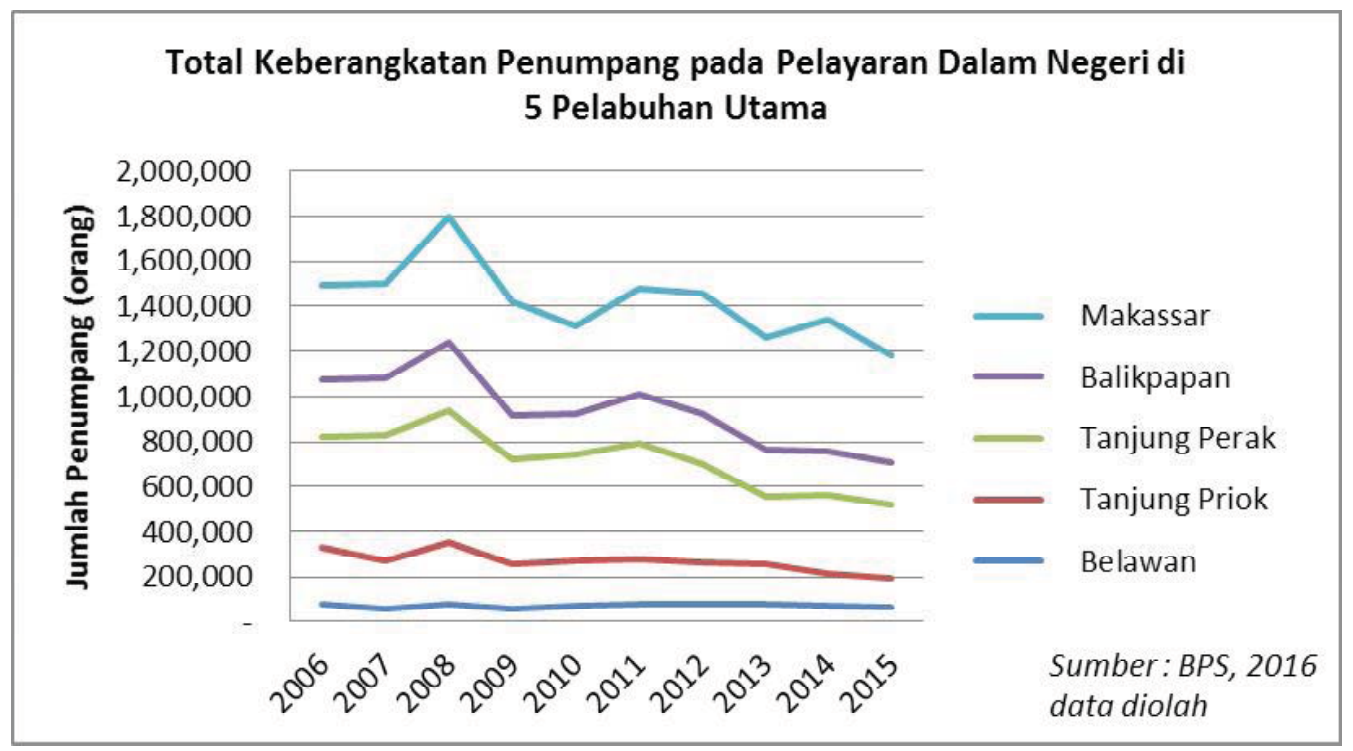

Gambar 1 Jumlah Penumpang Kapal di Lima Pelabuhan Utama

Ada 92 pelabuhan yang disinggahi kapal Pelni dengan 46 kantor cabang dan dilayani di 400 travel agen yang tersebar di seluruh Indonesia. Menurut catatan, jumlah penumpang yang diangkut BUMN ini paling tinggi terjadi pada tahun 2000, yang mencapai 8,6 juta orang. Angka ini menurun terus, terbalik dibandingkan dengan naik pesatnya penumpang pesawat, menjadi hanya 7,3 juta tahun 2001 dan menurun terus sampai tinggal 4,4 juta tahun 2015 (Annual Report PT Pelni, 2015). Kelas-kelas utama kapal-kapal penumpang PT Pelni sudah sejak tiga tahun terakhir hampir tak pernah diisi penumpang. Semua kelas kosong pada trayek jarak jauh, karena jangankan tarif kelas utama, tarif kelas ekonominya saja tak banyak beda dengan tarif angkutan udara, sementara masa perjalanan bisa 30 kali lebih lama. Pada Gambar 1 menyatakan jumlah penumpang laut dalam 10 tahun terakhir.

\section{Permasalahan}

Dari uraian di atas maka pokok permasalahan yang dijadikan fokus penelitian ini adalah sebagai berikut.
1. Bagaimana persepsi pelanggan terhadap kualitas pelayanan dari PT Pelni sebagai angkutan penumpang.

2. Faktor-faktor apa saja yang menjadi pertimbangan pelanggan dalam memilih jasa transportasi laut.

\section{Tujuan Penelitian}

Tujuan dari penelitian ini sebagai berikut.

1. Mengidentifikasi persepsi pelanggan terhadap kualitas pelayanan PT Pelni sebagai angkutan penumpang.

2. Mengidentifikasi faktor-faktor apa saja yang menjadi pertimbangan bagi pelanggan dalam memilih jasa transportasi laut.

\section{METODOLOGI PENELITIAN}

\section{Diagram Alir Penelitian}

Metode penelitian ini adalah deskriptif kuantitatif dan akan melalui tahapan proses penelitian seperti diagram alir yang terdapat pada Gambar 2. 

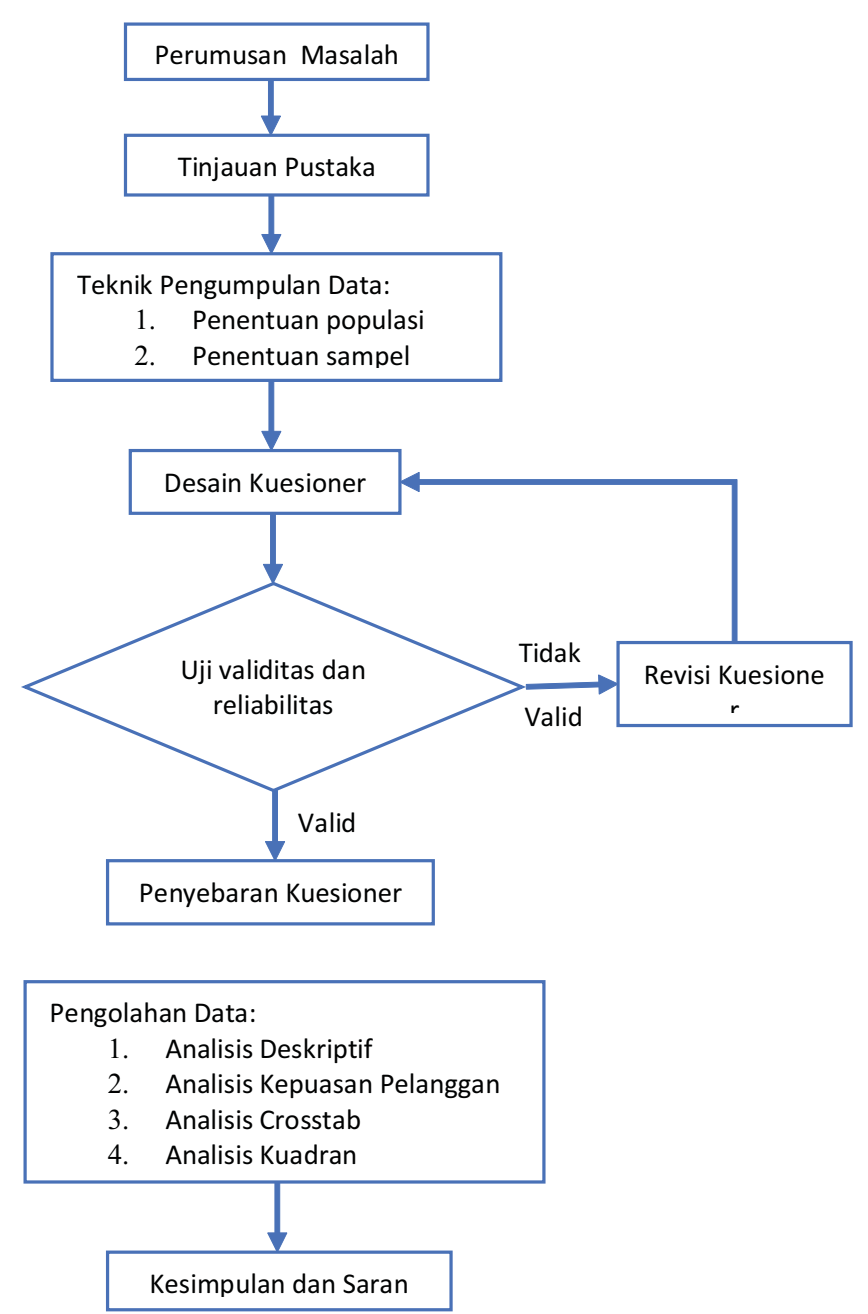

Gambar 2 Diagram Alur Penelitian

\section{Penentuan dan Pengambilan Sampel}

Populasi pada penelitian ini adalah pelanggan atau penumpang yang menggunakan jasa pelayaran PT Pelni. Teknik pengambilan sampel yang akan digunakan dalam penelitian ini adalah NonProbability Sampling. Yang artinya tidak semua anggota populasi mempunyai kesempatan yang sama untuk dijadikan sampel, akan dipilih oleh surveyor siapa saja yang dinilai mampu untuk dijadikan sampel.

Jumlah sampel minimum yang diambil (Derek L. Waller, 2008):

$$
n \geq \frac{\left(\sum \frac{\alpha}{2}\right)^{2} p \times q}{e^{2}}
$$

Di mana:

$\mathrm{n}=$ Jumlah sampel minimum yang diperlukan

$\alpha=$ Taraf signifikansi

$\mathrm{e}=$ Tingkat kesalahan maksimal antara nilai populasi dan sampel yang diizinkan

$\mathrm{p}=$ Persentase pelanggan yang menyatakan puas $(0,5)$

$\mathrm{q}=$ Persentase pelanggan yang menyatakan tidak puas $(0,5)$

Dengan menggunakan $\alpha=10 \%$ dan $\mathrm{e}=$ $10 \%$ dan mengasumsikan penumpang yang menyatakan puas sebesar $50 \%$ dan yang menyatakan tidak puas sebesar 50\%, maka persamaan di atas menjadi:

$\mathrm{n} \geq \frac{(1,6449)^{2} \mathrm{x}(0,5) \mathrm{x}(0,5)}{(0,1)^{2}}=67,638$

Berdasarkan rumus di atas, jumlah sampel minimum yang dibutuhkan adalah 68 responden. Namun untuk memudahkan pembagian sampel dan mengantisipasi pengisian yang salah, maka penelitian ini akan menggunakan 100 responden. Pembagian sampel akan dilakukan pada waktu penumpang naik dari Surabaya menuju Makasar.

\section{Identifikasi Variabel}

Variabel-variabel yang akan digunakan sebagai alat bantu penelitian mengacu pada berbagai peneliti (Andriotis \& Agiomirgianakis, Lobo, Petrick, Tonner, Qu \& Ping) yang mengusulkan delapan atribut dalam industri pelayaran yaitu: food quality, service quality, staff attractiveness, entertainment, ship facilities, ports of call, programs/places for children, and cabin quality. Dari delapan kategori atribut tersebut, dan dari tabel atribut service quality dunia pelayaran internasional menurut Andriotis et al. maka penulis membuat Tabel 1 variabel penelitian yang menyesuaikan dengan kondisi serta kebutuhan pelayaran di Indonesia. 
Tabel 1 Variabel Penelitian Industri Pelayaran yang Disesuaikan dengan Kondisi di Indonesia

\begin{tabular}{|c|c|c|c|}
\hline $\begin{array}{l}\text { Variabel } \\
\text { Servqual }\end{array}$ & Deskripsi & No. & Butir Pertanyaan \\
\hline \multirow[t]{11}{*}{ Tangible } & \multirow{11}{*}{$\begin{array}{l}\text { Meliputi fasilitas fisik, peralatan } \\
\text { dan penampilan }\end{array}$} & 1 & Kondisi tampak luar kapal yang seperti baru \\
\hline & & 2 & Perabotan di kapal yang berkualitas tinggi \\
\hline & & 3 & $\begin{array}{l}\text { Adanya fasilitas olahraga/kebugaran di kapal yang cukup } \\
\text { bagus }\end{array}$ \\
\hline & & 4 & $\begin{array}{l}\text { Adanya fasilitas perbelanjaan di kapal yang cukup } \\
\text { menarik }\end{array}$ \\
\hline & & 5 & $\begin{array}{l}\text { Penampilan Staf/kru dari kapal yang cukup } \\
\text { tampan/cantik }\end{array}$ \\
\hline & & 6 & $\begin{array}{l}\text { Adanya nomor pada tempat tidur yang cocok dengan } \\
\text { tiketnya sehingga tidak perlu berebut }\end{array}$ \\
\hline & & 7 & Ukuran kabin yang cukup besar \\
\hline & & 8 & Kamar yang sangat bersih \\
\hline & & 9 & Ruangan yang cukup tenang \\
\hline & & 10 & Ranjang/kasur/bantal yang cukup nyaman \\
\hline & & 11 & $\begin{array}{l}\text { Berbagai perlengkapan alat mandi yang tersedia di kamar } \\
\text { mandi }\end{array}$ \\
\hline \multirow[t]{7}{*}{ Reliability } & \multirow{7}{*}{$\begin{array}{l}\text { Kemampuan untuk memberikan } \\
\text { jasa secara akurat sesuai dengan } \\
\text { yang di janjikan }\end{array}$} & 12 & $\begin{array}{l}\text { Waktu kedatangan kapal dan keberangkatan yang tepat } \\
\text { waktu }\end{array}$ \\
\hline & & 13 & Antrean keluar masuk kapal yang cukup singkat \\
\hline & & 14 & Makanan di kapal pesiar yang masih segar \\
\hline & & 15 & $\begin{array}{l}\text { Banyaknya pilihan menu yang ditawarkan di restoran } \\
\text { kapal }\end{array}$ \\
\hline & & 16 & Sajian makanan di kapal yang cukup menarik \\
\hline & & 17 & Jam makan di kapal yang fleksibel \\
\hline & & 18 & Hiburan yang bagus di dalam kapal \\
\hline \multirow[t]{5}{*}{ Assurance } & \multirow{5}{*}{$\begin{array}{l}\text { Pengetahuan, keterampilan, } \\
\text { kesopanan karyawan dan } \\
\text { kemampuan memberi rasa aman } \\
\text { untuk mendapatkan } \\
\text { kepercayaan pelanggan }\end{array}$} & 19 & Keramahan petugas ticketing \\
\hline & & 20 & $\begin{array}{l}\text { Keramahan petugas di dalam kapal dalam melayani } \\
\text { penumpang }\end{array}$ \\
\hline & & 21 & Pengetahuan petugas akan rute kapal \\
\hline & & 22 & Keamanan di kapal \\
\hline & & 23 & Keamanan di pelabuhan \\
\hline \multirow[t]{3}{*}{ Empathy } & \multirow{3}{*}{$\begin{array}{l}\text { Kepedulian perhatian dan } \\
\text { kemudahan untuk } \\
\text { berkomunikasi, memahami } \\
\text { kebutuhan pelanggan dan } \\
\text { bersedia mendengarkan keluhan } \\
\text { pelanggannya }\end{array}$} & 24 & $\begin{array}{l}\text { Karyawan di kapal yang selalu berusaha melakukan yang } \\
\text { terbaik untuk penumpang }\end{array}$ \\
\hline & & 25 & Ketersediaan media komplain \\
\hline & & 26 & Ketersediaan informasi tentang kapal di internet \\
\hline \multirow[t]{3}{*}{ Responsiveness } & \multirow{3}{*}{$\begin{array}{l}\text { Kesediaan untuk membantu } \\
\text { pelanggan dan memberikan } \\
\text { layanan yang cepat }\end{array}$} & 27 & $\begin{array}{l}\text { Adanya petugas yang siap membantu dan mengatur naik } \\
\text { turunnya penumpang }\end{array}$ \\
\hline & & 28 & Adanya petugas mengatur system antrean \\
\hline & & 29 & Kecepatan layanan petugas ticketing \\
\hline
\end{tabular}

\section{Perhitungan Persepsi dan Harapan}

Pengolahan data tahap pertama yaitu menghitung nilai rata-rata masing-masing atribut penilaian. Penghitungan "Harapan" pelanggan me- ngenai pelayanan jasa menggunakan persamaan berikut:

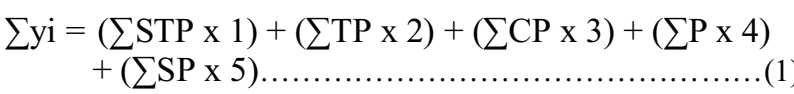


Keterangan:

$\sum y i=$ jumlah bobot jawaban pernyataan harapan variable $\mathrm{ke}-\mathrm{i}$

$\sum \mathrm{STP}=$ jumlah orang yang memilih jawaban sangat tidak terpenuhi

$\sum \mathrm{TP}=$ jumlah orang yang memilih jawaban tidak terpenuhi

$\Sigma \mathrm{CP}=$ jumlah orang yang memilih jawaban cukup terpenuhi

$\sum \mathrm{P} \quad=$ jumlah orang yang memilih jawaban terpenuhi

$\sum \mathrm{SP}=$ jumlah orang yang memilih jawaban sangat terpenuhi

$1,2,3,4,5=$ skor untuk skala Likert

Untuk rata-rata jawaban responden pada pernyataan harapan dapat dihitung dengan persamaan:

$$
\overline{Y_{l}}=\frac{\sum y \mathrm{i}}{n} \ldots
$$

Keterangan:

$\overline{Y_{z}}=$ rata-rata jawaban responden untuk pernyataan harapan atribut $\mathrm{ke}-\mathrm{i}$

$\sum y i=$ jumlah bobot jawaban pernyataan harapan atribut ke - i

$\mathrm{n} \quad=$ jumlah responden

Perhitungan kenyataan pelayanan yang dirasakan oleh pelanggan dilakukan sebagai berikut:

$\sum \mathrm{xi}=\left(\sum \mathrm{STP} \times 1\right)+\left(\sum \mathrm{TP} \times 2\right)+\left(\sum \mathrm{CP} \times 3\right)+\left(\sum \mathrm{P} \times 4\right)$

$+\left(\sum \mathrm{SP} \times 5\right)$

Keterangan:

$\sum x i=$ jumlah bobot jawaban pernyataan kenyataan variable $\mathrm{ke}-\mathrm{i}$

$\sum \mathrm{STP}=$ jumlah orang yang memilih jawaban sangat tidak terpenuhi

$\Sigma \mathrm{TP}=$ jumlah orang yang memilih jawaban tidak terpenuhi

$\Sigma \mathrm{CP}=$ jumlah orang yang memilih jawaban cukup terpenuhi

$\sum \mathrm{P} \quad=$ jumlah orang yang memilih jawaban terpenuhi

$\sum S P=$ jumlah orang yang memilih jawaban sangat terpenuhi

$1,2,3,4,5=$ skor untuk skala Likert
Untuk rata-rata jawaban responden pada pernyataan kenyataan dapat dihitung dengan persamaan:

$$
\overline{X_{\imath}}=\frac{\sum X \bar{i}}{n} \ldots
$$

Keterangan:

$\overline{X_{2}}=$ rata-rata jawaban responden untuk pernyataan kenyataan atribut $\mathrm{ke}-\mathrm{i}$

$\sum x i=$ jumlah bobot jawaban pernyataan kenyataan atribut $\mathrm{ke}-\mathrm{i}$

$\mathrm{n} \quad=$ jumlah responden

Setelah nilai rata-rata harapan dan kenyataan diketahui, kemudian dicari nilai dari gap masing-masing atribut dengan persamaan berikut:

$$
\text { Gap }=\bar{Y}-\bar{X} \ldots(5)
$$

Keterangan:

$\bar{X}=$ Nilai rata-rata kenyataan

$\bar{Y}=$ Nilai rata-rata harapan

Perhitungan rata-rata jawaban antara harapan pelanggan mengenai pelayanan jasa terhadap kenyataan pelayanan yang dirasakan oleh pelanggan berdasarkan lima dimensi Parasuraman's Servqual Model yang terdiri atas reliability (keandalan), responsiveness (daya tanggap), assurance (jaminan), empathy (empati), tangibles (bukti fisik).

Perhitungan rata-rata jawaban per dimensi nilai Gap untuk harapan:

$$
\overline{X D_{l}}=\frac{\sum X V / 1}{n} .
$$

Keterangan:

$\overline{X D_{2}}=$ rata-rata dimensi atribut ke-i untuk harapan

$\Sigma \overline{X V \imath}=$ jumlah nilai rata-rata atribut pernyataan per dimensi ke-i harapan

$\mathrm{n} \quad=$ jumlah pernyataan per dimensi

Penghitungan rata-rata jawaban per dimensi nilai gap 5 untuk kenyataan:

$$
\overline{Y D l}=\frac{\sum Y V_{1}}{n}
$$


Keterangan:

$\overline{Y D_{2}}=$ rata-rata dimensi atribut ke-i untuk kenyataan

$\sum \overline{Y V \imath}=$ jumlah nilai rata-rata atribut pernyataan per dimensi ke-i kenyataan

$\mathrm{N}=$ jumlah pernyataan per dimensi

\section{HASIL DAN PEMBAHASAN}

\section{Uji Validitas dan Reliabilitas}

Uji validitas dan reliabilitas dilakukan untuk mengetahui keandalan dari kuesioner yang merupakan instrument untuk mendapatkan data. Tahap ini penting dilakukan untuk mengetahui kemampuan masing-masing atribut pertanyaan pada instrument. Pengujian kuesioner pada tahap awal ini dilakukan dengan menyebarkan kuesioner yang ditujukan kepada 30 responden penumpang kapal Pelni dengan rute perjalanan dari Surabaya ke Makassar. Selanjutnya data hasil survei tahap awal ini diuji untuk mengetahui apakah semua atribut pertanyaan dalam kue- sioner sudah memenuhi ketentuan validitas dan reliabilitas.

\section{Uji validitas}

Uji validitas dilakukan dengan teknik Correct Item-Total Correlation. Analisis ini dilakukan dengan mengorelasikan masing-masing skor item pertanyaan dengan skor total yang dibandingkan dengan nilai kritis koefisien produk momen dengan taraf signifikan 5\%. Kriteria pengujian yaitu jika $r$ hitung $>r$ tabel (uji dua arah dengan sig. 0,05) maka item pertanyaan berkorelasi signifikan terhadap skor total (dinyatakan valid). Jika $r$ hitung $<$ tabel (uji 2 sisi dengan sig. 0,05) atau $r$ hitung negatif, maka instrumen atau item-item pertanyaan tidak berkorelasi signifikan terhadap skor total (dinyatakan tidak valid). Jumlah responden yaitu 30, maka nilai df yaitu n-2 $=28$. Maka didapatkan nilai $r$ tabel yaitu 0,361 . Berikut hasil uji validitas pada harapan objek amatan.

Tabel 2 Hasil Uji Validitas Atribut Pertanyaan

\begin{tabular}{|c|c|c|c|c|c|}
\hline \multirow{2}{*}{\multicolumn{2}{|c|}{$\frac{\text { Item Pertanyaan }}{\text { Tangible }}$}} & \multicolumn{4}{|c|}{ Korelasi terhadap skor total } \\
\hline & & \multirow{2}{*}{\begin{tabular}{c|} 
Harapan \\
0.70
\end{tabular}} & \multirow{2}{*}{\begin{tabular}{|c|} 
Keterangan \\
Valid \\
\end{tabular}} & \multirow{2}{*}{$\frac{\text { Kenyataan }}{0.45}$} & \multirow{2}{*}{$\frac{\text { Keterangan }}{\text { Valid }}$} \\
\hline 1 & $\begin{array}{l}\text { Pentingkah bagi anda kondisi tampak luar kapal yang } \\
\text { seperti baru? }\end{array}$ & & & & \\
\hline 2 & $\begin{array}{l}\text { Pentingkah bagi anda perabotan di kapal yang berkualitas } \\
\text { tinggi? }\end{array}$ & 0.53 & Valid & 0.43 & Valid \\
\hline 3 & $\begin{array}{l}\text { Pentingkah bagi anda adanya fasilitas olahraga/kebugaran } \\
\text { di kapal yang cukup bagus? }\end{array}$ & 0.65 & Valid & 0.5 & Valid \\
\hline 4 & $\begin{array}{l}\text { Pentingkah bagi anda adanya fasilitas perbelanjaan di kapal } \\
\text { yang cukup menarik? }\end{array}$ & 0.82 & Valid & 0.43 & Valid \\
\hline 5 & $\begin{array}{l}\text { Pentingkah bagi anda penampilan Staf/kru dari kapal yang } \\
\text { cukup tampan/cantik? }\end{array}$ & 0.75 & Valid & 0.60 & Valid \\
\hline 6 & $\begin{array}{l}\text { Pentingkah bagi anda adanya nomor pada tempat tidur } \\
\text { yang cocok dengan tiketnya. Sehingga tidak perlu berebut? }\end{array}$ & 0.75 & Valid & 0.4 & Valid \\
\hline 7 & Pentingkah bagi anda ukuran kabin yang cukup besar? & 0.76 & Valid & 0.67 & Valid \\
\hline 8 & Pentingkah bagi anda kamar yang sangat bersih? & 0.69 & Valid & 0.55 & Valid \\
\hline 9 & Pentingkah bagi anda ruangan yang cukup tenang? & 0.80 & Valid & 0.61 & Valid \\
\hline 10 & $\begin{array}{l}\text { Pentingkah bagi anda ranjang/kasur/bantal yang cukup } \\
\text { nyaman? }\end{array}$ & 0.75 & Valid & 0.67 & Valid \\
\hline 11 & $\begin{array}{l}\text { Pentingkah bagi anda berbagai perlengkapan alat mandi } \\
\text { yang tersedia di kamar mandi? }\end{array}$ & 0.73 & Valid & 0.65 & Valid \\
\hline 12 & $\begin{array}{l}\text { Pentingkah bagi anda waktu kedatangan kapal dan } \\
\text { keberangkatan yang tepat waktu? }\end{array}$ & 0.86 & Valid & 0.57 & Valid \\
\hline
\end{tabular}




\begin{tabular}{|c|c|c|c|c|c|}
\hline 13 & $\begin{array}{l}\text { Pentingkah bagi anda antrean keluar masuk kapal yang } \\
\text { cukup singkat? }\end{array}$ & 0.74 & Valid & 0.54 & Valid \\
\hline 14 & $\begin{array}{l}\text { Pentingkah bagi anda makanan di kapal pesiar yang masih } \\
\text { segar? }\end{array}$ & 0.82 & Valid & 0.734 & Valid \\
\hline 15 & $\begin{array}{l}\text { Pentingkah bagi anda banyaknya pilihan menu yang } \\
\text { ditawarkan di restoran kapal? }\end{array}$ & 0.82 & Valid & 0.784 & Valid \\
\hline 16 & $\begin{array}{l}\text { Pentingkah bagi anda sajian makanan di kapal yang cukup } \\
\text { menarik? }\end{array}$ & 0.78 & Valid & 0.734 & Valid \\
\hline 17 & Pentingkah bagi anda jam makan di kapal yang fleksibel? & 0.85 & Valid & 0.448 & Valid \\
\hline 18 & Pentingkah bagi anda hiburan yang bagus di dalam kapal? & 0.78 & Valid & 0.608 & Valid \\
\hline 19 & Pentingkah bagi anda keramahan petugas ticketing? & 0,86 & Valid & 0,66 & Valid \\
\hline 20 & $\begin{array}{l}\text { Pentingkah bagi anda keramahan petugas di dalam kapal } \\
\text { dalam melayani penumpang? }\end{array}$ & 0,88 & Valid & 0,7 & Valid \\
\hline 21 & Pentingkah bagi anda pengetahuan petugas akan rute kapal? & 0,9 & Valid & 0,68 & Valid \\
\hline 22 & Pentingkah bagi anda keamanan di kapal? & 0,9 & Valid & 0,81 & Valid \\
\hline 23 & Pentingkah bagi anda keamanan di pelabuhan? & 0,9 & Valid & 0,81 & Valid \\
\hline 24 & $\begin{array}{l}\text { Pentingkah bagi anda karyawan di kapal yang selalu } \\
\text { berusaha melakukan yang terbaik untuk penumpang? }\end{array}$ & 0,88 & Valid & 0,79 & Valid \\
\hline 25 & Pentingkah bagi anda ketersediaan media komplain? & 0,8 & Valid & 0,70 & Valid \\
\hline 26 & $\begin{array}{l}\text { Pentingkah bagi anda ketersediaan informasi tentang kapal } \\
\text { di internet? }\end{array}$ & 0,82 & Valid & 0,68 & Valid \\
\hline 27 & $\begin{array}{l}\text { Pentingkah bagi anda adanya petugas yang siap membantu } \\
\text { dan mengatur naik turunnya penumpang? }\end{array}$ & 0,79 & Valid & 0,81 & Valid \\
\hline 28 & $\begin{array}{l}\text { Pentingkah bagi anda adanya petugas mengatur system } \\
\text { antrean? }\end{array}$ & 0,85 & Valid & 0,81 & Valid \\
\hline 29 & Pentingkah bagi anda kecepatan layanan petugas ticketing? & 0,9 & Valid & 0,79 & Valid \\
\hline
\end{tabular}

\section{Uji Reabilitas}

Setelah mengetahui beberapa item pertanyaan yang valid dan tidak valid, kemudian dilakukan uji reliabilitas dengan menggunakan rumus perkiraan “croncbach's Alpha”. Uji reliabilitas dilakukan untuk mengetahui apakah instrument yang digunakan reliabel. Suatu instrument dikatakan variabel jika instrument ukur tersebut selalu menunjukkan hasil yang sama selama variabel tidak berubah. Instrument yang reliabel belum tentu valid, sedangkan instrumen yang valid pasti reliabel. Kriteria pengujian reliabilitas yaitu jika nilai cronbach;s alpha lebih kecil dari nilai batas minimum yaitu 0,6 (nunnally 1967), maka item tersebut tidak reliabel, sebaliknya jika nilai cronbach's alpha yang diperoleh lebih besar dari 0,6 maka item tersebut dinyatakan reliabel. Berikut ini adalah hasil pengujian reliabilitas.

Tabel 3 Hasil uji reliabilitas

\begin{tabular}{|c|c|c|}
\hline Variabel & Nilai Alpha Cronbach's & Keterangan \\
\hline Persepsi & 0,942 & Reliable \\
\hline Harapan & 0,981 & Reliable \\
\hline
\end{tabular}

\section{Analisis Persepsi dan Harapan}

Dari hasil kuesioner yang didapatkan, kemudian didata serta diolah dengan menggunakan metode Servqual. Perhitungan menggunakan persamaan 1 dan 2 untuk mendapatkan bobot dan nilai rata-rata masing-masing atribut pertanyaan harapan. Kemudian dengan menggunakan persamaan 3 dan 4 untuk mendapatkan 
bobot dan nilai rata-rata masing-masing atribut pertanyaan persepsi atau kenyataan. Setelah nilai rata-rata dari kenyataan dan harapan diketahui, kemudian dicari nilai gap antara keduanya dengan persamaan 5. Berikut ini tabel hasil semua perhitungan tersebut.

Tabel 4 Nilai Rata-Rata Harapan-Kenyataan dan Nilai Gap

\begin{tabular}{|c|c|c|c|c|c|}
\hline \multirow[b]{2}{*}{$\begin{array}{l}\text { No. } \\
\text { Atribut }\end{array}$} & \multicolumn{2}{|c|}{$\begin{array}{l}\text { Harapan } \\
\text { Pelayanan }\end{array}$} & \multicolumn{2}{|c|}{$\begin{array}{l}\text { Kenyataan } \\
\text { Pelayanan }\end{array}$} & \multirow[b]{2}{*}{$\begin{array}{l}\text { Nilai } \\
\text { Gap }\end{array}$} \\
\hline & $\begin{array}{c}\text { Nilai } \\
\text { Pembo- } \\
\text { botan }\end{array}$ & $\begin{array}{c}\text { Rata-rata } \\
\text { Harapan }\end{array}$ & $\begin{array}{l}\text { Nilai } \\
\text { Pembo- } \\
\text { botan }\end{array}$ & $\begin{array}{l}\text { Rata-rata } \\
\text { Kenyataan }\end{array}$ & \\
\hline 1 & 395 & 3,95 & 286 & 2,86 & $-1,09$ \\
\hline 2 & 420 & 4,2 & 309 & 3,09 & $-1,11$ \\
\hline 3 & 350 & 3,5 & 253 & 2,53 & $-0,97$ \\
\hline 4 & 460 & 4,6 & 313 & 3,13 & $-1,47$ \\
\hline 5 & 410 & 4,1 & 359 & 3,59 & $-0,51$ \\
\hline 6 & 460 & 4,6 & 301 & 3,01 & $-1,59$ \\
\hline 7 & 450 & 4,5 & 247 & 2,47 & $-2,03$ \\
\hline 8 & 420 & 4,2 & 253 & 2,53 & $-1,67$ \\
\hline 9 & 400 & 4 & 239 & 2,39 & $-1,61$ \\
\hline 10 & 380 & 3,8 & 295 & 2,95 & $-0,85$ \\
\hline 11 & 380 & 3,8 & 239 & 2,39 & $-1,41$ \\
\hline 12 & 414 & 4,14 & 337 & 3,37 & $-0,77$ \\
\hline 13 & 383 & 3,83 & 290 & 2,9 & $-0,93$ \\
\hline 14 & 444 & 4,44 & 365 & 3,65 & $-0,79$ \\
\hline 15 & 375 & 3,75 & 345 & 3,45 & $\begin{array}{l}-0,3 \\
\end{array}$ \\
\hline 16 & 371 & 3,71 & 318 & 3,18 & $-0,53$ \\
\hline 17 & 400 & 4 & 307 & 3,07 & $-0,93$ \\
\hline 18 & 375 & 3,75 & 327 & 3,27 & $-0,48$ \\
\hline 19 & 416 & 4,16 & 360 & 3,6 & $-0,56$ \\
\hline 20 & 424 & 4,24 & 349 & 3,49 & $-0,75$ \\
\hline 21 & 407 & 4,07 & 391 & 3,91 & $-0,16$ \\
\hline 22 & 464 & 4,64 & 317 & 3,17 & $-1,47$ \\
\hline 23 & 443 & 4,43 & 310 & 3,1 & $-1,33$ \\
\hline 24 & 380 & 3,8 & 334 & 3,34 & $-0,46$ \\
\hline 25 & 390 & 3,9 & 305 & 3,05 & $-0,85$ \\
\hline 26 & 425 & 4,25 & 349 & 3,49 & $-0,76$ \\
\hline 27 & 431 & 4,31 & 351 & 3,51 & $-0,8$ \\
\hline 28 & 410 & 4,1 & 381 & 3,81 & $-0,29$ \\
\hline 29 & 372 & 3,72 & 355 & 3,55 & $-0,17$ \\
\hline
\end{tabular}

Untuk mengetahui nilai rata-rata dari setiap dimensi servqual, dilakukan perhitungan ratarata dengan mengelompokkan masing-masing atribut berdasarkan dimensi servqual. Perhitungan menggunakan persamaan 6 dan 7. Berikut hasil perhitungan pada tabel 5 .
Tabel 5 Nilai Rata-Rata dan Gap Setiap Dimensi Servqual

\begin{tabular}{|l|c|c|c|c|c|}
\hline \multicolumn{1}{|c|}{$\begin{array}{c}\text { Dimensi } \\
\text { Pernyataan }\end{array}$} & $\begin{array}{c}\text { Jumlah } \\
\text { Rata-rata } \\
\text { Harapan }\end{array}$ & $\begin{array}{c}\text { Jumlah } \\
\text { Rata-rata } \\
\text { Kenyataan }\end{array}$ & $\begin{array}{c}\text { Nilai } \\
\text { Harapan }\end{array}$ & $\begin{array}{c}\text { Nilai } \\
\text { Kenya- } \\
\text { taan }\end{array}$ & $\begin{array}{c}\text { Nilai } \\
\text { Gap }\end{array}$ \\
\hline Tangible & 37,65 & 30,94 & 4,11 & 2,81 & $-1,3$ \\
\hline Reliabilty & 27,62 & 22,89 & 3,94 & 3,27 & $-0,67$ \\
\hline Assurance & 21,54 & 17,27 & 4,3 & 3,46 & $-0,84$ \\
\hline Empathy & 12,87 & 9,61 & 3,98 & 3,2 & $-0,78$ \\
\hline Responsiveness & 12,13 & 10,87 & 4,04 & 3,62 & $-0,42$ \\
\hline
\end{tabular}

Dari Tabel 5 dapat diketahui atribut pernyataan yang memiliki kesenjangan terbesar sampai atribut yang memiliki kesenjangan terkecil. Semakin besar gap yang dihasilkan dari sebuah perhitungan Servqual ini, semakin kurang baiknya kualitas pelayanan jasa tersebut. Nilai gap terbesar terdapat dalam dimensi Tangible yaitu $-1,3$. Sedangkan nilai gap terkecil terdapat pada dimensi Responsiveness yaitu $-0,42$. Oleh karena itu, prioritas perbaikan kualitas pelayanan jasa dilakukan dari gap atau kesenjangan terbesar, dalam hal ini yaitu pada dimensi tangible. Sebaliknya, semakin kecilnya suatu gap (gap tersebut mendekati nol atau positif) semakin baik kualitas pelayanan jasa tersebut.

\section{Analisis Diagram Kartesius}

Analisis diagram kartesius berfungsi untuk memudahkan mengetahui dan memahami prioritas dari suatu atribut. Secara ringkas, diagram kartesius membagi suatu nilai atribut menjadi empat bagian atau kuadran. Pada kuadran pertama menunjukkan bahwa harapan dan kenyataan sama-sama tinggi, berarti posisi atribut ini sudah sesuai dengan pelayanan yang diharapkan. Pada kuadran kedua menunjukkan nilai kenyataan lebih baik daripada harapan konsumen; hal ini berarti pelayanan yang diberikan cenderung berlebihan. Pada kuadran ketiga menunjukkan harapan dan kenyataan sama-sama rendah; hal ini berarti atribut ini dirasa kurang perlu atau 
kurang prioritas bagi konsumen. Pada kuadran keempat menunjukkan harapan yang lebih tinggi daripada kenyataan; hal ini berarti pelayanan yang diberikan kurang baik dari apa yang diharapkan konsumen, sehingga perlu ditingkatkan lagi.

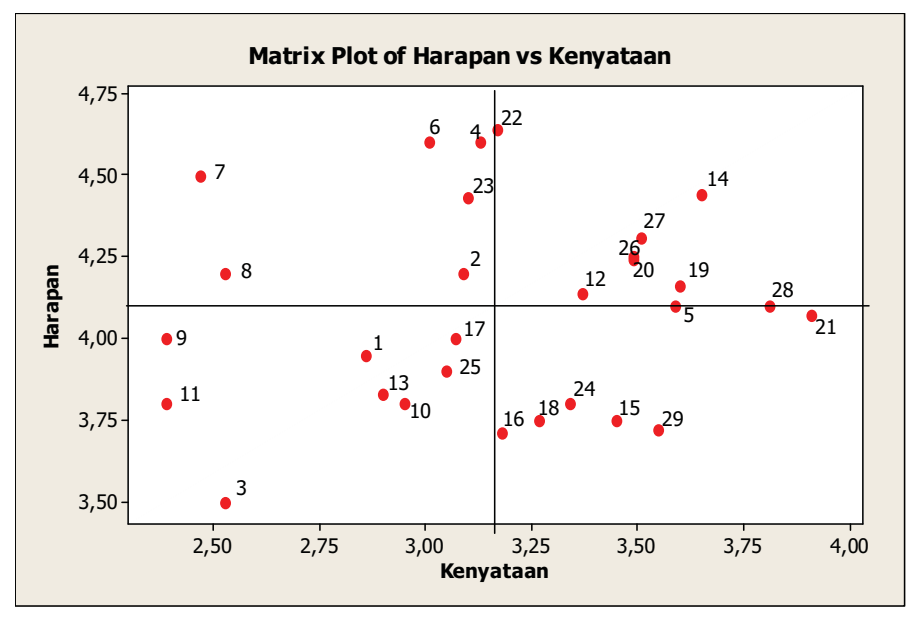

Gambar 2 Diagram Kartesius Harapan-Kenyataan

\section{Analisis Kuadran I}

Atribut yang terdapat dalam kuadran ini yaitu nomor 12, 14 yang masuk dalam kategori Reliability. Masing-masing nomor atribut tersebut yaitu ketepatan waktu kedatangan dan keberangkatan kapal (12), makanan sajian dalam kondisi segar (14). Konsumen memiliki penilaian bahwa dua poin atribut tersebut dirasakan sudah sesuai dengan harapan. Atribut nomor 19, 20, 22 termasuk dalam kategori dimensi assurance. Masing-masing atribut yaitu keramahan petugas tiket (19), keramahan pelayanan saat di kapal (21), dan keamanan di kapal (22). Responden merasa bahwa ketiga hal tersebut pelayanannya sudah sesuai dengan harapan. Atribut nomor 26 termasuk dalam kategori Empathy yaitu ketersediaan informasi kapal melalui internet. Hal ini menunjukkan bahwa informasi yang diberikan sudah cukup memenuhi harapan konsumen. Atribut nomor 27, 28 masuk dalam kategori dimensi Responsiveness. Masing-masing yaitu petugas membantu mengatur naik turun penumpang (27), dan pengaturan sistem antrean. Dua hal tersebut sudah dirasa sesuai harapan oleh responden.

Sembilan atribut tersebut sudah baik dalam pemenuhan harapan kepada konsumen, sehingga ke depannya diharapkan tetap mempertahankan kinerja yang baik tersebut.

\section{Analisis Kuadran II}

Atribut yang terdapat dalam kuadran II ini yaitu nomor 5 yang masuk dalam kategori tangible. Harapan responden mengenai penampilan staff/kru kapal sudah terpenuhi dengan baik. Atribut nomor 15, 16, 18 termasuk dalam kategori dimensi reliability. Masing-masing atribut yaitu keragaman pilihan menu di restoran kapal (15), kemasan makanan (16), dan hiburan yang bagus (18). Responden merasa bahwa pelayanan tentang ragam pilihan makanan, kemasan yang menarik, dan hiburan yang disajikan oleh pihak kapal sudah sesuai harapan. Atribut nomor 21 termasuk dalam kategori Assurance yaitu pengetahuan petugas kapal terhadap rute perjalanan. Hal ini menunjukkan bahwa informasi rute yang diberikan oleh para petugas kapal sudah cukup informatif dan memenuhi harapan konsumen. Atribut nomor 24 masuk dalam kategori dimensi Empathy yaitu petugas kapal selalu siap dalam melayani kebutuhan konsumen. Responden menilai bahwa para petugas selalu siap sedia sewaktu dibutuhkan untuk melayani kebutuhan penumpang. Atribut terakhir yang masuk dalam kuadran II yaitu nomor 29 yaitu tentang kecepatan petugas tiket dalam pelayanan kepada konsumen. Responden menilai bahwa kinerja yang diberikan sudah memenuhi harapan konsumen dalam pelayanan. 
Secara keseluruhan, atribut yang masuk dalam kategori kuadran II sudah baik dalam memenuhi kebutuhan pelanggan. Meskipun termasuk dalam prioritas kuadran II, masing-masing poin dalam atribut ini diharapkan agar tetap dijaga performa kinerjanya.

\section{Analisis Kuadran III}

Atribut yang terdapat dalam kuadran ini yaitu nomor 1, 3, 9, 10, 11 yang masuk dalam kategori tangible. Masing-masing nomor atribut tersebut yaitu kondisi kapal yang bagus dan tampak baru (1), fasilitas olahraga (3), ruangan yang tenang (9), ketersediaan peralatan mandi (11). Konsumen memiliki penilaian bahwa dua poin atribut tersebut dirasakan belum dengan harapan. Atribut nomor 13, 17 termasuk dalam kategori dimensi reliability. Masing-masing atribut yaitu kelancaran antrean keluar masuk kapal (13), dan jam makan yang fleksibel (17). Responden merasa bahwa ketiga hal tersebut pelayanannya belum sesuai dengan harapan. Atribut nomor 25 termasuk dalam kategori empathy yaitu ketersediaan media komplain yang memadai bagi konsumen. Hal ini menunjukkan bahwa media complain belum sesuai harapan. Hal ini mungkin kurang adanya pengetahuan oleh penumpang di mana seharusnya mengadukan complain tentang pelayanan yang dirasa kurang sesuai dengan harapan.

Delapan atribut tersebut bagi responden dirasa masih belum memenuhi harapan. Namun skala prioritas bagi pemenuhan harapan konsumen masuk dalam kategori kuadran III, yang skala prioritasnya juga tidak begitu utama bagi konsumen. Namun, tetap sebaiknya terus dilakukan perbaikan pada delapan atribut yang masuk dalam kategori kuadran III ini.

\section{Analisis Kuadran 4}

Atribut yang terdapat dalam kuadran ini yaitu nomor 2, 4, 6, 7, 8 yang masuk dalam kategori tangible. Masing-masing nomor atribut tersebut yaitu perabotan kapal yang berkualitas tinggi (2), fasilitas perbelanjaan di kapal (4), ketersediaan tempat tidur dengan nomor sesuai tiket (6), ukuran kabin yang besar (7), dan kondisi kamar yang bersih (8). Konsumen memiliki penilaian bahwa lima poin atribut tersebut dirasakan sangat belum sesuai dengan harapan. Fasilitas mengenai tempat belanja yang sesuai harapan konsumen terkait dengan kurang beragamnya barang yang dijual di market yang terdapat di kapal, serta nilai jual yang jauh lebih mahal dibanding harga pada umumnya. Penomoran tempat tidur dan kabin yang sesuai dengan nomor tiket dibutuhkan oleh penumpang. Hal tersebut menghindari adanya rebutan tempat tidur antar-sesama penumpang. Kabin yang disediakan pada kapal dirasa masih kurang luas bagi konsumen sehingga apa yang diharapkan tidak sesuai dengan kondisi nyata. Selain itu juga masalah kebersihan kamar bagi responden masih dirasa kurang terjamin kebersihannya. Atribut nomor 23 termasuk dalam kategori dimensi assurance yaitu tentang keamanan di pelabuhan. Responden merasa bahwa keamanan di pelabuhan masih kurang baik dan tidak sesuai dengan harapan konsumen.

Enam atribut tersebut bagi responden dirasa masih sangat kurang baik dan tidak sesuai dengan harapan konsumen. Kuadran IV dirasa sangat penting bagi konsumen namun dalam pelaksanaan kenyataannya masih jauh dari harapan konsumen. Atribut-atribut ini sebaiknya dilakukan perbaikan pelayanan karena merupakan masuk dalam skala prioritas utama dan harapan konsumen yang tinggi. 


\section{KESIMPULAN DAN SARAN}

\section{Kesimpulan}

Berdasarkan hasil analisis dan pembahasan penelitian, dapat disimpulkan beberapa hal sebagai berikut.

1. Berdasarkan analisis servqual, terlihat seluruh dimensi memperlihatkan nilai gap yang negative. Hal ini mengindikasikan masih adanya ketidaksesuaian antara harapan penumpang kapal Pelni dengan pelayanan yang diterima. Nilai gap terbesar terdapat dalam dimensi tangible yaitu $-1,3$ sedangkan nilai gap terkecil terdapat pada dimensi responsiveness yaitu 0,42 .

2. Atribut servqual yang merupakan prioritas pelanggan yang harus diperbaiki karena sangat penting bagi penumpang kapal, yaitu berdasarkan analisis diagram kartesius kuadrant 1 sebagai berikut. Tempat tidur dengan nomor sesuai tiket, ukuran kabin, kebersihan kamar, tempat perbelanjaan di kapal dengan harga yang normal, dan perabotan kapal yang berkualitas.

\section{Saran}

Saran yang dapat diberikan kepada manajemen PT Pelni untuk meningkatkan kepuasan pelanggan berdasarkan servqual ini adalah sebagai berikut.

1. Pemberian nomor tempat tidur yang sesuai dengan tiket sehingga penumpang bisa mendapat kepastian akan tempat tidur. Tidak perlu berebut. Ini juga akan membuat penumpang tidak berebut masuk kapal. Bisa santai, jadi akan mengurangi antrean yang berdesakdesakan seperti saat ini

2. Ukuran kabin diperluas, atau diberi sekat antar-penumpang sebelahnya sehingga ada privasi dan lebih nyaman.
3. Kebersihan kamar ditingkatkan, dan dipantau terus menerus selama pelayaran.

4. Tempat perbelanjaan diperbaiki dan ditambah. Selain itu, yang penting harga barang-barang yang dijual tidak terlalu tinggi perbedaannya dengan harga di pasaran.

5. Perabotan kapal diperbaharui. Dan ditingkatkan kualitasnya.

6. Perlunya penelitian lebih lanjut untuk memadukan persepsi pelanggan dengan persepsi manajemen PT Pelni terkait dengan kepuasan pelanggan.

\section{REFERENSI}

Andriotis, K. \& Agiomirgianakis, G. 2010. Cruise Visitors' Experience in a Mediterranean Port of Call. International Journal of Tourism Research, 12(4), 390-404.

Andriotis, K., Agiomirgianakis, G., \& Mihiotis, A. 2007. Tourist Vacation Preferences - The Case of Mass Tourists to Crete. Tourism Analysis, 12(1/2), 51-63.

Endah A. 2016. Random Sampling. Handout Mata Kuliah Tesis. Surabaya: Magister Manajemen Teknologi ITS.

De la Vina, L. \& Ford, J. 2001. Logistic Regression Analysis of Cruise Vacation Market Potential: Demographic and Trip Attribute Perception Factors. Journal of Travel Research, 39(4), 406-410.

Parasuraman, A., Zeithaml, V. A., \& Berry, L. L. 1988. SERVQUAL: a Multiple-Item Scale for Measuring Consumer Perceptions of Service Quality. Journal of Retailing, 64(1), 12-40.

Yarnal, C. M. \& Kerstetter, D. 2005. Casting off: an Exploration of Cruise Ship Space, Group Tour Behaviour, and Social Interaction. Journal of Travel Research, 43, 368-379. 
Zeithaml, V.A., Berry, L., \& Parasuraman, A. 1996. The Behavioral Consequences of Service Quality. Journal of Marketing, 60, 31-46.

Gibson, P. \& Bentley, M. 2006. A Study of Impacts e Cruise Tourism and the South West of England. Journal of Travel \& Tourism Marketing, 20(3/4), 63-77.

Henthorne, T.L. 2000. An Analysis of Expenditures by Cruise Ship Passengers in Jamaica. Journal of Travel Research, 38, 246250.

Hosany, S. \& Witham, M. 2010. Dimensions of Cruisers' Experiences, Satisfaction, and Intention to Recommend. Journal of Travel Research, 49(3), 351-364.

Hung, K. \& Petrick, J.F. 2011. Why do You Cruise? Exploring the Motivations for Taking Cruise Holidays, and Construction of a Cruising Motivation Scale. Tourism Management, 32, 386-393.
Luoh, H.F. \& Tsaur, S.H. 2009. Physical Attractiveness Stereotypes and Service Quality in customer e-Server Encounters. The Service Industries Journal, 29(8), 1093-1104.

Petrick, J., Tonner, C., \& Quinn, C. 2006. The Utilization of Critical Incident Technique to Examine Cruise Passengers' Repurchase Intentions. Journal of Travel Research, 44(3), 273-280.

Teye, V.B. \& Leclerc, D. 1998. Product and Service Delivery Satisfaction among North American Cruise Passengers. Tourism Management, 19(2), 153-160.

Veronneau, S. \& Roy, J. 2009. Global Service Supply Chains: an Empirical Study of Current Practices and Challenges of a Cruise Line Corporation. Tourism Management, 30, 128-139.

Wood, R.E. 2000. Caribbean Cruise Tourism: Globalization at Sea. Annals of Tourism Research, 27(2), 345-370. 